\title{
Preoperative analysis of upper lip in patients with upper cleft lip/ palate before lip repair
}

\author{
Junyan Jing ${ }^{1}$, Xiaoxuan $\mathrm{Chen}^{1}$, Bing Shi ${ }^{2}$, Yufeng Wang ${ }^{1}$, Yongbin $\mathrm{Mou}^{3}$, Yong $\mathrm{Lu}^{1}$ \\ ${ }^{1}$ Department of Oral and Maxillofacial Surgery, Nanjing Stomatological Hospital, Medical School of Nanjing University, Nanjing, China; \\ ${ }^{2}$ Department of Cleft Lip and Palate Surgery, West China College of Stomatology, Sichuan University, Chengdu, China; ${ }^{3}$ Department of Oral \\ Implantology, Nanjing Stomatological Hospital, Medical School of Nanjing University, Nanjing, China \\ Contributions: (I) Conception and design: B Shi, Y Lu; (II) Administrative support: Y Mou; (III) Provision of study materials or patients: Y Mou, Y \\ Lu; (IV) Collection and assembly of data: J Jing, X Chen; (V) Data analysis and interpretation: All authors; (VI) Manuscript writing: All authors; (VII) \\ Final approval of manuscript: All authors. \\ "These authors contributed equally to this work. \\ Correspondence to: Yong Lu. Department of Oral and Maxillofacial Surgery, Nanjing Stomatological Hospital, Medical School of Nanjing University, \\ No. 30 Zhongyang Road, Nanjing 210008, China. Email: cleftsurgery@163.com; Yongbin Mou. Department of Oral Implantology, Nanjing \\ Stomatological Hospital, Medical School of Nanjing University, No. 30 Zhongyang Road, Nanjing 210008, China. Email: yongbinmou@163.com.
}

Background: The postoperative morphological appearances vary widely patients with unilateral cleft lip with or without cleft palate (UCL/P), whether it is complete or incomplete cleft. The main reason of bilateral lip asymmetry after cleft lip surgery lies in the lack of personalized measurement and design before surgery. In this study, we aim to individually investigate areas of the upper lip on cleft and non-cleft sides in patients with unilateral cleft lip with or without cleft palate (UCL/P).

Methods: Ninety-two patients with UCL/P (group 1: <1 year, group 2: 1-2 years) were included in the study. Group 1 included 37 patients with incomplete UCL/P and 29 with complete UCL/P; group 2 included 11 and 15 patients, respectively. The total area of the upper lip on the cleft side (Q8) was divided into Q3, Q4, and Q5 (further divided into a1 and a2), and the upper lip on the non-cleft side (Q7) was divided into Q2 and Q1 (further divided into A1 and A2). Area ratios between the cleft and the non-cleft sides were calculated, and certain parameters were tested for correlations with these ratios.

Results: Values of Q8/Q7 were partially overlapped between patients with complete and incomplete UCL/P. Significant correlations were noted between differences in height of the philtrum column $(\mathrm{a}-\mathrm{h})$ and the prolabial area ratio between the cleft and the non-cleft side $(\mathrm{Q} 3 / \mathrm{Q} 2)(\mathrm{P}=0.032)$. Moreover, a significant correlation was noted between a1/A1 and the ratio of the lateral labial area between the cleft and the noncleft side (Q5/Q1) ( $\mathrm{P}=0.001)$.

Conclusions: The conventional classification of unilateral cleft lip as incomplete and complete does not completely and accurately reflect individual malformations. Therefore, it is necessary to analyze unilateral cleft lips individually to determine the repair technique and to predict postoperative outcomes.

Keywords: Upper lip; cleft lip; philtrum column; prolabial area

Submitted Feb 24, 2021. Accepted for publication Apr 22, 2021.

doi: $10.21037 / \mathrm{atm}-21-1424$

View this article at: http://dx.doi.org/10.21037/atm-21-1424

\section{Introduction}

According to available literature, morphological appearances immediately after surgery and the further development of upper lips vary widely among patients with unilateral cleft lip with or without cleft palate (UCL/P), based on complete or incomplete nature of the cleft, even when performed by the most experienced surgeons. Few studies 
Table 1 Linear parameters measured in the present study

\begin{tabular}{|c|c|}
\hline $\begin{array}{l}\text { Linear } \\
\text { parameters }\end{array}$ & Definition \\
\hline Line a & Height of philtrum column on non-cleft side \\
\hline Line $b$ & Height of philtrum \\
\hline Line c & Width of upper lip on the non-cleft side \\
\hline Line d & $\begin{array}{l}\text { Distance between alar base and ipsilateral } \\
\text { commissure on the non-cleft side }\end{array}$ \\
\hline Line e & $\begin{array}{l}\text { Distance between the central point and the } \\
\text { peak point of Cupid's bow on the non-cleft side }\end{array}$ \\
\hline Line $f$ & Width of nasal floor on the non-cleft side \\
\hline Line $g$ & $\begin{array}{l}\text { the distance between the central point and } \\
\text { Peak point of Cupid's bow on the medial part of } \\
\text { cleft side }\end{array}$ \\
\hline Line $\mathrm{h}$ & height of philtrum column on the cleft side \\
\hline Line i & $\begin{array}{l}\text { Distance between the peak point of Cupid's } \\
\text { bow and the end point of the vermilion on the } \\
\text { medial part of cleft side }\end{array}$ \\
\hline Line j & $\begin{array}{l}\text { Width of nasal floor on the medial part of cleft } \\
\text { side }\end{array}$ \\
\hline Line $\mathrm{K}$ & Width of upper lip on the cleft side \\
\hline Line L & $\begin{array}{l}\text { the distance between alar base and ipsilateral } \\
\text { commissure on the cleft side }\end{array}$ \\
\hline
\end{tabular}

have quantitatively analyzed $(1,2)$, whereas others have qualitatively described (3-6), such differences. In addition, postoperative morphological appearance of lips was better in some patients with complete UCL/P compared with those with incomplete $\mathrm{UCL} / \mathrm{P}$, even when the most experienced surgeons operated using a single technique (7). In terms of surgical technique, Nakajima suggested that methods designed for repair of complete unilateral cleft lips should not be used to repair incomplete unilateral cleft lips (8), while Chowdri suggested that either technique can be used for repair of unilateral cleft lips (9).

A major reason for the lack of postoperative morphological symmetry in cases of unilateral cleft lip is the characteristic differences in lips among patients before surgery. Conventionally, cleft lips are classified as complete and incomplete, which is too general to accurately reflect the wide variations observed in cleft lip cases. Therefore, in order to resolve this issue, we evaluated areas of the upper lip in individual patients based on geometric principles.

The aim of the present study was to report basic information regarding labial areas before primary cheiloplasty, differences in labial areas between cleft and non-cleft sides among patients, changes in growth area ratios between cleft and non-cleft sides, and parameters that are significantly correlated with these ratios.

We present the following article in accordance with the STROBE reporting checklist (available at http://dx.doi. org/10.21037/atm-21-1424).

\section{Methods}

\section{Patients and photo data acquisition}

Patients with UCL/P enrolled in this study were from Nanjing Stomatological Hospital (Nanjing, China). The present study included 92 Chinese babies with UCL/P (48 incomplete cleft lips and 44 complete cleft lips). Sixty-six of them were aged $<1$ year old (group 1) and 26 of them were aged 1-2 years old (group 2).

The study was conducted in accordance with the Declaration of Helsinki (as revised in 2013). The study was approved by ethics board of Nanjing Stomatological Hospital (No. YW-2000NL-002) and informed consent was taken from all individual participants.

Linear data of the upper lip were directly obtained from the face when a baby received general anesthesia immediately before surgery. Major landmarks were defined according to Farkas' description (10).

\section{Grouping and calculation}

For the purpose of the present study, we divided the upper lip into the cleft and the non-cleft side according to line b, which connects the midpoint of the Cupid's bow and the midpoint of the base of the columella. Certain linear parameters were measured and certain areas were calculated (Tables 1 and 2, respectively). Figure 1 shows these parameters.

Based on the geometry of the patients' lips, the area on the non-cleft side (Q7) was divided into Q1 and Q2, and that on the cleft side (Q8) was divided into Q3, Q4, and Q5. The area of the lateral lip on the cleft side (Q6) included Q4 and Q5. To compare Q8 and Q7, we assessed Q3/ $\mathrm{Q} 2$ and $(\mathrm{Q} 4+\mathrm{Q} 5) / \mathrm{Q} 1$ in each patient. On comparing the lateral lip between the cleft and the non-cleft side, Q4 was significantly less than Q1 and Q5, so Q4 could be ignored, and the lateral lip comparison was simplified to Q5/Q1. Q1 was further divided into A1 and A2, and Q5 was further divided into a1 and a2 (Figure 2). Certain parameters were 
Table 2 Areas calculated in the present study

\begin{tabular}{ll}
\hline $\begin{array}{l}\text { Parameters } \\
\text { of area }\end{array}$ & \multicolumn{1}{c}{ Definition } \\
\hline Q1 & Area of lateral lip on non-cleft side \\
Q2 & Area of prolabial on non-cleft side \\
Q3 & Area of prolabial on the cleft side \\
Q4 & Area of lateral lip on the medial part of cleft side \\
Q5 & Area of lateral lip on the lateral part of cleft side \\
Q6 & Area of lateral lip on the cleft side (Q4+Q5) \\
Q7 & Area on the non-cleft side (Q1+Q2) \\
Q8 & Area on the cleft side (Q3+Q4+Q5) \\
A1 & Area of lateral part of Q1 \\
A2 & Area of medial part of Q1 \\
a1 & Area of lateral part of Q5 \\
a2 & Area of medial part of Q5 \\
\hline
\end{tabular}

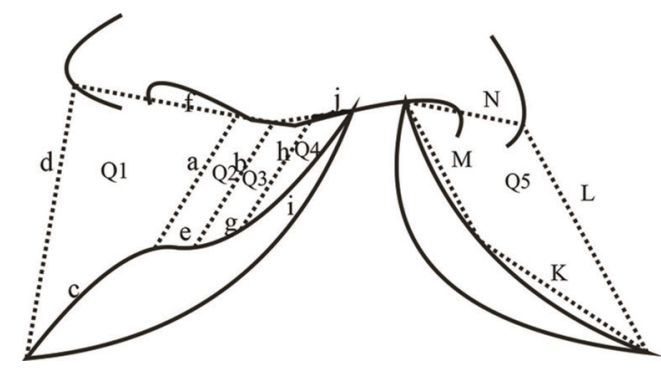

Figure 1 Schematic representation of linear and area parameters used in the present study.

tested to determine correlations among these area ratios.

\section{Statistical analysis}

Statistical analysis was conducted using the SPSS version 11.0 (SPSS, Chicago, IL, USA). Mean values of the 2 age groups, as well as mean values of the 2 types of cleft lip (complete and incomplete), were compared using Student's $t$-test. The linear correlation coefficient $\mathrm{R}$ and $\mathrm{P}$ values were calculated to describe correlations. $\mathrm{P}<0.05$ indicated a significant difference.

\section{Results}

Areas of Q1-Q8 are summarized in Table 3. In general, the

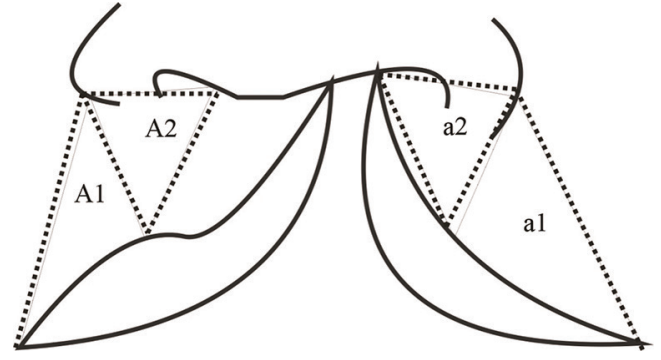

Figure 2 Further division of Q1 and Q5 (Q1 was further divided into $\mathrm{A} 1$ and $\mathrm{A} 2$, and $\mathrm{Q} 5$ was divided into a1 and a2).

mean area of the non-cleft side was significantly larger than that of the cleft side in both age groups and in both types of cleft lip $(\mathrm{P}<0.05)$. Individual analysis revealed that the range of Q8/Q7 varied widely (45-112\%). In fact, Q8 was larger than Q7 in certain cases. Moreover, values of Q8/Q7 partially overlapped between patients with complete and incomplete cleft lip (Table 4).

In total, Q8/Q7 was $<80 \%$ in 54 (19 incomplete and 35 complete) cases (Table 4), 5 of the patients' Q8/Q7 was $<60 \%$ who had complete cleft lips. Q8/Q7 was $>90 \%$ in 18 (16 incomplete and 2 complete) cases; 9 of the patients' Q8/ Q7 was $>100 \%$ who had incomplete cleft lips. Furthermore, we observed a trend that Q8/Q7 reduced with growth, that is, he discrepancy between the cleft and the non-cleft side increased significantly with growth (Table 4).

Regarding prolabium, a significant correlation $(R=-0.710$, $\mathrm{P}=0.032)$ was noted in the linear discrepancy between lines a and $\mathrm{h}(\mathrm{a}-\mathrm{h})$ and Q3/Q2 (Figure 3 and Table 5). In addition, a significant correlation $(\mathrm{R}=0.97, \mathrm{P}=0.001)$ was observed between a1/A1 and Q5/Q1 (Figure 4 and Table 6). No significant correlation was noted among the other parameters.

\section{Discussion}

$\mathrm{UCL} / \mathrm{P}$ is the most common deformity in newborn infants with cleft lip or palate (11). Some attempts have been made to describe the complicated deformity of UCL. Although several studies have described classifications of UCL based on length of the cleft (12-14), previously published studies describing other preoperative features of cleft lip are limited $(15,16)$. Individual analysis is important to evaluate the degree of malformation, to select the appropriate repair technique, and to predict postoperative morphological outcomes. 
Table 3 Mean areas of Q1-Q8

\begin{tabular}{|c|c|c|c|c|c|c|c|c|c|}
\hline Group & \multicolumn{3}{|c|}{ Non-cleft side $\left(\mathrm{mm}^{2}\right)$} & \multicolumn{5}{|c|}{ Cleft side } & $\begin{array}{l}\text { No. } \\
\text { cases }\end{array}$ \\
\hline \multicolumn{10}{|c|}{ Group 1 (<1 year old) } \\
\hline Incomplete UCL & 138.72 & 24.97 & 163.67 & 21.20 & 10.16 & 111.53 & 121.67 & 142.89 & 37 \\
\hline Complete UCL & 157.38 & 25.34 & 183.72 & 21.40 & 10.50 & 106.58 & 117.08 & 138.48 & 29 \\
\hline Incomplete UCL & 149.78 & 28.34 & 178.6 & 23.17 & 8.88 & 94.45 & 103.33 & 126.5 & 11 \\
\hline Complete UCL & 146.65 & 30.10 & 176.8 & 23.920 & 8.53 & 95.72 & 104.25 & 128.2 & 15 \\
\hline
\end{tabular}

UCL, unilateral cleft lip.

Table 4 Values of Q8/Q7

\begin{tabular}{|c|c|c|c|c|c|c|c|c|c|c|c|c|c|c|c|c|}
\hline & \multicolumn{8}{|c|}{ Group 1} & \multicolumn{8}{|c|}{ Group 2} \\
\hline $\begin{array}{l}\text { Incomplete } \\
\text { UCL/P }\end{array}$ & 37 & 0 & 0 & 6 & 5 & 10 & 7 & 9 & 11 & 0 & 1 & 2 & 5 & 3 & 0 & 0 \\
\hline $\begin{array}{l}\text { Complete } \\
\text { UCL/P }\end{array}$ & 29 & 0 & 4 & 10 & 11 & 4 & 0 & 0 & 15 & 1 & 0 & 6 & 3 & 3 & 2 & 0 \\
\hline
\end{tabular}

UCL/P, unilateral cleft lip with or without cleft palate.

Anthropometry is a useful tool to assess soft tissue anatomy of the upper lip, and also provides clinicians with quantitative information regarding malformed structures and regions $(17,18)$. Various methods are used to assess cleft lip deformities, such as anthropometry (19), casts (20), photographs $(21,22)$, video imaging $(23,24), 3 \mathrm{D}$ computed tomography $(25,26)$, and $3 \mathrm{D}$ laser scanning $(27,28)$. In the present study, we performed measurements on live subjects because it is a simple, non-invasive technique with minimal equipment cost. Moreover, the scope for error during measurement is limited when a baby is under general anesthesia.

Available literature suggests that measurements, such as distance, angle, ratio, area, and volume are related to the evaluation of UCL $(29,30)$. We selected area as the measurement tool, because it is the most appropriate parameter to reflect tissue defects and tissue malposition $(31,32)$. We calculated area according to geometric principles.

Even when operated by surgeons with limited experience, the postoperative morphological appearance of some patients with complete UCL/P were better than that of some patients with incomplete UCL/P. Regardless of the type of conventional classification of cleft lip used, postoperative appearances of different lips varied widely following the same surgical technique. Therefore, conventional classification was insufficient to accurately reflect various characteristics of cleft lip, and therefore, complete evaluation of UCL is warranted.

In the present study, among incomplete cleft lip cases, the area on the cleft side was much less than that on the non-cleft side in some cases, with Q8/Q7 being $<60 \%$. Conversely, among complete cleft lip cases, the area on the cleft side was similar to that on the non-cleft side in some cases, with Q8/Q7 being $>90 \%$. This would perhaps explain why sometimes postoperative appearance in incomplete cleft lip cases was worse than that in complete cleft lip cases.

We thought it was inappropriate to attribute the cleft lip to tissue defects alone in group 1 patients, because in some of these patients, areas on the cleft side were larger than those on the non-cleft side, with Q8/Q7 being up to $112 \%$. However, in group 2, there were no cases of the cleft side area being larger than the non-cleft side area. Notably, rapid growth occurs between 1 and 2 years of age (33), and the inconsistent growth between the cleft and the non-cleft 


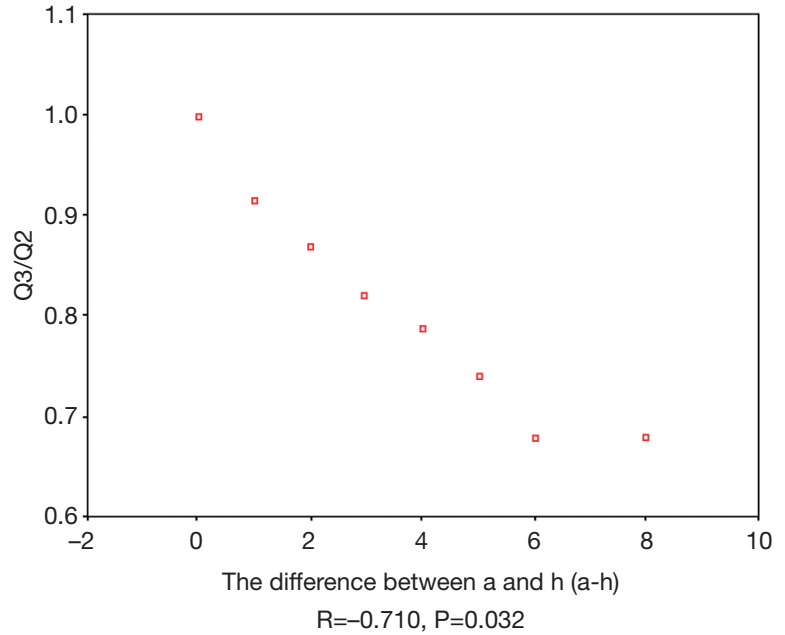

Figure 3 The correlation between a-h and Q3/Q2 in the present study. $\mathrm{x}$ axis means the $t$-test value of a and $\mathrm{h}$, where a is the height of philtrum column in the non-cleft side and $\mathrm{h}$ is the height of philtrum column in the cleft side. Pair $t$-test is performed on and $\mathrm{h}$ values of all samples. The $\mathrm{y}$ axis is the Q3/Q2 ratio, where Q3 is the area of the philtrum in the cleft side and Q2 is the area of the philtrum in the non-cleft side.

Table 5 Relationship between $\mathrm{a}-\mathrm{h}$ and Q3/Q2

\begin{tabular}{lcc}
\hline $\mathrm{a}-\mathrm{h}(\mathrm{mm})$ & No. cases & Q3/Q2 (\%) \\
\hline 0 & 1 & 100 \\
1 & 10 & 91.7 \\
2 & 22 & 86.8 \\
3 & 19 & 82.2 \\
4 & 24 & 78.9 \\
5 & 11 & 74.4 \\
6 & 4 & 67.5 \\
7 & 0 & 0 \\
8 & 1 & 68.0. \\
\hline
\end{tabular}

side between 1 and 2 years of age would aggravate the area discrepancy. Cleft lip can therefore be gradually attributed to tissue defects with growth.

A significant correlation was observed between values of $\mathrm{a}-\mathrm{h}$ and $\mathrm{Q} 3 / \mathrm{Q} 2(\mathrm{R}=-0.710, \mathrm{P}=0.032)$. Moreover, a significant correlation was noted between a1/A1 and Q5/ $\mathrm{Q} 1$ on the lateral lip $(\mathrm{R}=0.97, \mathrm{P}=0.001)$.

Based on geometric principles, the quadrilateral Q2 was organized by lines $b$, a, and e, and the upper width of the

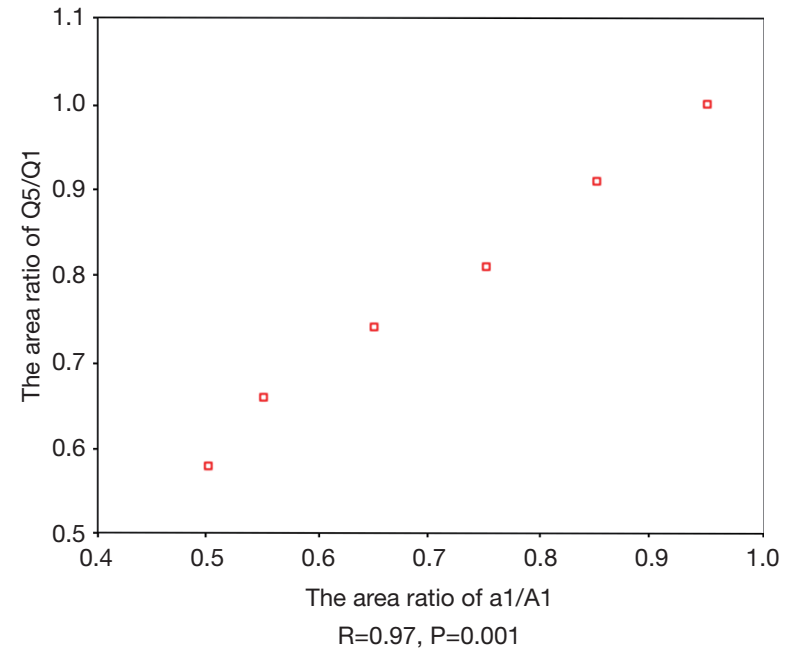

Figure 4 The correlation between a1/A1 and Q5/Q1 in the present study. $x$ axis means the ratio of a1/A1. The lines between the alars and the lip peaks divide Q1 into A2 of the nasal base area and $\mathrm{A} 1$ of the lateral labial area, and divide Q5 into $\mathrm{A} 2$ of the nasal base area and $\mathrm{A} 1$ of the lateral labial lip, respectively. $\mathrm{Y}$ axis is the ratio of Q5/Q1, where Q1 is the area of lip in the non-cleft side and Q5 is the area of cleft lip in the cleft-side.

Table 6 Relationship between a1/A1and Q5/Q1

\begin{tabular}{lcc}
\hline a1/A1 & No. cases & Q5/Q1 (\%) \\
\hline$<50 \%$ & 3 & 57.68 \\
$51-60 \%$ & 18 & 65.7 \\
$61-70 \%$ & 17 & 74.26 \\
$71-80 \%$ & 14 & 80.85 \\
$81-90 \%$ & 5 & 91.43 \\
$>90 \%$ & 0 & $\geq 100$ \\
\hline
\end{tabular}

prolabium on the non-cleft side, while the quadrilateral Q3 was organized by lines b, h, and g, and the upper width of the prolabium on the cleft side. Line a was shared by Q2 and Q3. Based on our design and observations, line e was equal to line $\mathrm{g}$, and the upper width of the prolabium did not differ significantly between the cleft and the noncleft side. Therefore, the only variable between Q2 and Q3 was the difference between lines a and $\mathrm{h}(\mathrm{a}-\mathrm{h})$. This would explain the significant correlation observed between values of a-h and Q3/Q2.

The lateral lip comparison could be simplified to Q5/ Q1 as we mentioned earlier. Q1 was further divided into 
$\mathrm{A} 1$ and $\mathrm{A} 2$, and Q5 was further divided into a1 and a2. No significant differences were noted between a2 and A2 $(\mathrm{P}>0.05)$ in both complete and incomplete cleft lip patients. Hence, the comparison between Q5 and Q1 could be further simplified to a1/A1. This would explain the significant correlation observed between a1/A1 and the area ratio of the lateral lip.

Based on the results, parameters that reflect area ratios between the cleft and the non-cleft sides were meaningful. With the help of these parameters, we can approximately estimate the level of tissue defect, as well as postoperative appearance. Moreover, we can analyze which part of the upper lip (prolabial or lateral lip) is the primary causative factor for deformity and select the appropriate treatment approach.

Several studies have assessed the effects of a single repair technique or the skill of a single surgeon based on postoperative appearance (34-36). This method may not be appropriate because discrepancies of areas between the non-cleft and the cleft side among patients before repair are different. Preoperative appearance can influence postoperative morphology.

\section{Conclusions}

The traditional classification of unilateral cleft lip cannot completely and accurately reflect the degree of individual deformity. In this paper, we innovatively use the form of computing area to personalize the evaluation of unilateral cleft lip, based on geometric principles, in order to identify repair techniques and predict postoperative outcomes.

\section{Acknowledgments}

Funding: This work was funded by the Medical Science and Technology Development Foundation, Nanjing Department of Health (YKK15117, QRX11125).

\section{Footnote}

Reporting Checklist: The authors have completed the STROBE reporting checklist. Available at http://dx.doi. org/10.21037/atm-21-1424

Data Sharing Statement: Available at http://dx.doi. org/10.21037/atm-21-1424

Conflicts of Interest: All authors have completed the ICMJE uniform disclosure form (available at http://dx.doi. org/10.21037/atm-21-1424). The authors have no conflicts of interest to declare.

Ethical Statement: The authors are accountable for all aspects of the work in ensuring that questions related to the accuracy or integrity of any part of the work are appropriately investigated and resolved. The study was conducted in accordance with the Declaration of Helsinki (as revised in 2013). The study was approved by ethics board of Nanjing Stomatological Hospital (No. YW-2000NL-002) and informed consent was taken from all individual participants.

Open Access Statement: This is an Open Access article distributed in accordance with the Creative Commons Attribution-NonCommercial-NoDerivs 4.0 International License (CC BY-NC-ND 4.0), which permits the noncommercial replication and distribution of the article with the strict proviso that no changes or edits are made and the original work is properly cited (including links to both the formal publication through the relevant DOI and the license). See: https://creativecommons.org/licenses/by-nc-nd/4.0/.

\section{References}

1. Farkas LG, Katic MJ, Forrest CR, et al. International anthropometric study of facial morphology in various ethnic groups/races. J Craniofac Surg 2005;16:615-46.

2. Tse RW, Mercan E, Fisher DM, et al. Unilateral Cleft Lip Nasal Deformity: Foundation-Based Approach to Primary Rhinoplasty. Plast Reconstr Surg 2019;144:1138-49.

3. Dong Y, Zhao Y, Bai S, et al. Three-dimensional anthropometric analysis of the Chinese nose. J Plast Reconstr Aesthet Surg 2010;63:1832-9.

4. He ZJ, Jian XC, Wu XS, et al. Anthropometric measurement and analysis of the external nasal soft tissue in 119 young Han Chinese adults. J Craniofac Surg 2009;20:1347-51.

5. Kim SH, Whang E, Choi HG, et al. Analysis of the midface, focusing on the nose: an anthropometric study in young Koreans. J Craniofac Surg 2010;21:1941-4.

6. Li KZ, Guo S, Sun Q, et al. Anthropometric nasal analysis of Han Chinese young adults. J Craniomaxillofac Surg 2014;42:153-8.

7. Kluba S, Bopp C, Bacher M, et al. Morphological analysis of the lip and nose following cleft lip repair with simultaneous partial primary rhinoplasty: A prospective study over 4 
years. J Craniomaxillofac Surg 2015;43:599-605.

8. Nakajima T, Yoshimura Y, Yoneda K, et al. Primary repair of an incomplete unilateral cleft lip: avoiding an elongated lip and achieving a straight suture line. Br J Plast Surg 1998;51:511-6.

9. Chowdri NA, Darzi MA, Ashraf MM. A comparative study of surgical results with rotation-advancement and triangular flap techniques in unilateral cleft lip. Br J Plast Surg 1990;43:551-6.

10. Farkas LG, Hajnis K, Posnick JC. Anthropometric and anthroposcopic findings of the nasal and facial region in cleft patients before and after primary lip and palate repair. Cleft Palate Craniofac J 1993;30:1-12.

11. Al-Omari I, Millett DT, Ayoub AF. Methods of assessment of cleft-related facial deformity: a review. Cleft Palate Craniofac J 2005;42:145-56.

12. Basta MN, Goldstein JA, Wilson AJ, et al. A modified V-Y chondromucosal composite flap for correction of secondary cleft nasal deformity: photogrammetric analysis of a casecontrol study. Plast Reconstr Surg 2014;134:94-101.

13. Henry C, Samson T, Mackay D. Evidence-based medicine: The cleft lip nasal deformity. Plast Reconstr Surg 2014;133:1276-88.

14. Sharma VP, Bella H, Cadier MM, et al. Outcomes in facial aesthetics in cleft lip and palate surgery: a systematic review. J Plast Reconstr Aesthet Surg 2012;65:1233-45.

15. Masuoka H, Kawai K, Morimoto N, et al. Open rhinoplasty using conchal cartilage during childhood to correct unilateral cleft-lip nasal deformities. J Plast Reconstr Aesthet Surg 2012;65:857-63.

16. McDaniel JM, Alleyne B, Gosain AK. Secondary cleft nasoplasty at primary school age: quantitative evaluation of the efficacy of resorbable plates. Plast Reconstr Surg 2013;132:933-43.

17. Anic-Milosevic S, Anic-Milosevic S, Lapter-Varga M, et al. Analysis of the soft tissue profile in Croatians with normal occlusions and well-balanced faces. Eur J Orthod 2011;33:305-10.

18. Bavbek NC, Tuncer BB, Tuncer C, et al. Cephalometric assessment of soft tissue morphology of patients with acromegaly. Aust Orthod J 2016;32:48-54.

19. Fudalej P, Katsaros C, Hozyasz K, et al. Nasolabial symmetry and aesthetics in children with complete unilateral cleft lip and palate. Br J Oral Maxillofac Surg 2012;50:621-5.

20. Xu Y, Li J, Zhao S, et al. Four-dimensional changes of nasolabial positions in unilateral cleft lip and palate. J Craniofac Surg 2013;24:473-8.
21. Kuijpers MA, Chiu Y'T, Nada RM, et al. Threedimensional imaging methods for quantitative analysis of facial soft tissues and skeletal morphology in patients with orofacial clefts: a systematic review. PLoS One 2014;9:e93442.

22. Sforza C, Grandi G, De Menezes M, et al. Age- and sex-related changes in the normal human external nose. Forensic Sci Int 2011;204:205 e1-9.

23. Doddi NM, Eccles R. The role of anthropometric measurements in nasal surgery and research: a systematic review. Clin Otolaryngol 2010;35:277-83.

24. Mosmuller D, Tan R, Mulder F, et al. The use and reliability of SymNose for quantitative measurement of the nose and lip in unilateral cleft lip and palate patients. J Craniomaxillofac Surg 2016;44:1515-21.

25. Gatti GL, Freda N, Giacomina A, et al. Cleft Lip and Palate Repair. J Craniofac Surg 2017;28:1918-24.

26. Kiya K, Oyama T, Taniguchi M, et al. Simultaneous correction of deviated columella and wide nostril floor using the Y-V advancement in unilateral cleft lip nasal deformities. J Plast Reconstr Aesthet Surg 2014;67:721-4.

27. Laverde BL, da Silva Freitas R, Nasser IJ. Assessment of Labionasal Structures in Patients With Unilateral Cleft Lip. J Craniofac Surg 2016;27:78-81.

28. Taub PJ, Piccolo P. Cleft Lip Repair: Through the Looking Glass. J Craniofac Surg 2016;27:2031-5.

29. Aras I, Baykal D, Bulut M, et al. Evaluation of mandibular hard and soft tissues in cleft patients. J Istanb Univ Fac Dent 2017;51:14-22.

30. McIntyre GT, Mossey PA. Asymmetry of the craniofacial skeleton in the parents of children with a cleft lip, with or without a cleft palate, or an isolated cleft palate. Eur J Orthod 2010;32:177-85.

31. Kim Y, Hong BW, Kim SJ, et al. A population-based tissue probability map-driven level set method for fully automated mammographic density estimations. Med Phys 2014;41:071905.

32. Rodriguez GE, Gonzalez DM, Monachelli GM, et al. Morphological abnormalities in mitochondria of the skin of patients with sporadic amyotrophic lateral sclerosis. Arq Neuropsiquiatr 2012;70:40-4.

33. Li L, Liao L, Zhong Y, et al. Variation trends of the postoperative outcomes for unilateral cleft lip patients by modified Mohler and Tennison-Randall cheiloplasties. J Craniomaxillofac Surg 2016;44:1786-95.

34. Dogan E, Seckin O. Maxillary protraction in patients with unilateral cleft lip and palate : Evaluation of soft and hard tissues using the Alt-RAMEC protocol. J Orofac Orthop 
Page 8 of 8

2020;81:209-19.

35. Wang X, Wang Q, Sun Y, et al. Three-Dimensional Computed Tomography Scan Analysis of Secondary Labial Deformities in Patients With Unilateral Cleft Lip/ Cleft Palate After Revisional Surgery. Ann Plast Surg 2021;86:S273-S81.

36. Yuan XP, Guo QR, Geng CL, et al. Subjective and

Cite this article as: Jing J, Chen X, Shi B, Wang Y, Mou Y, Lu Y. Preoperative analysis of upper lip in patients with upper cleft lip/palate before lip repair. Ann Transl Med 2021;9(8):698. doi: $10.21037 /$ atm-21-1424 objective evaluation and correlation analysis of preand post- operation in patients with structural nasal obstruction. Zhonghua Er Bi Yan Hou Tou Jing Wai Ke Za Zhi 2016;51:902-8.

(English Language Editor: R. Scott) 